\title{
A SIMPLE AND COST-EFFECTIVE METHOD FOR DNA EXTRACTION SUITABLE FOR PCR IN "SUCUPIRA BRANCA"
}

\author{
Jailson do Nascimento SILVA ${ }^{1}$ (D), João Paulo Gomes VIANA ${ }^{2}$ (D) Marcones Ferreira COSTA $^{3}$ (iD), \\ Gisele Holanda de SÁ ${ }^{4}$ (D), Maria Fernanda da Costa GOMES ${ }^{5}$ (iD), Lidiane de Lima FEITOZA ${ }^{6}$ (D), \\ Sérgio Emílio dos Santos VALENTE ${ }^{6}$ iD
}

\footnotetext{
${ }^{1}$ Department of Education, Federal Institute of Piauí, Valença, Piauí, Brazil.

2 University of Illinois, Urbana-Champaign, Illinois, United States of America.

${ }^{3}$ Federal University of Piauí, Floriano, Piauí, Brazil.

${ }^{4}$ Postgraduate Program in Genetics and Breeding, Federal University of Piauí, Teresina, Piauí, Brazil.

${ }^{5}$ Department of Biology, State University of Piauí, São Raimundo Nonato, Piauí, Brazil.

${ }^{6}$ Department of Biology, Federal University of Piauí, Teresina, Piauí, Brazil.
}

Corresponding author:

Sérgio Emílio dos Santos Valente

Email: svalente@ufpi.edu.br

How to cite: SILVA, J.N., et al. A simple and cost-effective method for DNA extraction suitable for PCR in "sucupira branca". Bioscience Journal. 2021, 37, e37092. https://doi.org/10.14393/BJ-v37n0a2021-54133

\begin{abstract}
"Sucupira branca" is a plant found in the Brazilian Cerrado and is adapted to low fertility soils, and its fruit extract has anti-inflammatory, healing, antiulcerogenic, antimicrobial, cercaricidal, leishmanicidal and antioxidant activities. Furthermore, it provides protection against oxidative stress, is a natural biocontrol agent of Aedes aegypti, has very resistant wood, is a melliferous plant and has been used in reforestation programs. The development of conservation strategies is important for maintaining diversity in natural populations of "sucupira branca" since these populations are in the process of genetic erosion. Molecular biology techniques, which are important for characterizing the genetic diversity of plants to develop conservation strategies, require sufficient high-quality genomic deoxyribonucleic acid (DNA). This study aimed to compare five methods to extract DNA from "sucupira branca". The quality and concentration of DNA were revealed by agarose gel electrophoresis, and only the protocols of Dellaporta, Wood and Hicks et al. (1983) and Khanuja et al. (1999) did not result in satisfactory quantities of DNA. When PCR (Polymerase Chain Reaction) was performed with three inter-simple sequence repeat (ISSR) primers, DNA was successfully amplified from extractions performed with the protocols proposed by Doyle and Doyle (1987), Romano and Brasileiro (1998) and Ferreira and Grattapaglia (1995), which are less expensive than commercial purification kits. These protocols resulted in DNA of sufficient quality and quantity after the amplification reactions were performed.
\end{abstract}

Keywords: Conservation. DNA Isolation. Extraction. ISSR. Pterodon emarginatus.

\section{Introduction}

Pterodon emarginatus Vog. (Leguminosae) is a tree popularly known as "sucupira branca". It is widely found in the Brazilian Cerrado and is adapted to low fertility soils (Brandão and Ferreira 1991).

"Sucupira branca" is widely used in traditional medicine in Brazil since its fruit extract has antiinflammatory, healing, antiulcerogenic, antimicrobial, cercaricidal, and antioxidant activities (Carvalho et al. 1999; Donati et al. 2015; Oliveira et al. 2018). The oil obtained from the seed has protection against oxidative stress and leishmanicidal activity and is a natural biocontrol agent of Aedes aegypti (Oliveira et al. 2016). 
Furthermore, it is a melliferous plant with potential for urban reforestation and landscaping; it has very resistant and long-lasting wood, which is used in the manufacture of furniture and in civil and naval construction (Silva-Junior 2005). Because it is a highly resistant plant tolerant to direct light, "sucupira branca" has been used in reforestation programs in degraded areas and permanent preservation areas (Lorenzi 1992).

Impacts caused by anthropogenic disturbances such as deforestation and fragmentation induce changes in the organization and distribution of genetic diversity (Corrêa and Bertuci-Junior 2012). Accordingly, the development of conservation strategies is important for maintaining diversity (Lacerda and Kageyama 2003). From this perspective, to carry out molecular studies associated with genetic conservation, it is necessary to obtain deoxyribonucleic acid (DNA) of appropriate quality and quantity for amplification with the selected primers and to obtain reliable and reproducible bands (Mondragon-Jacobo et al. 2000).

Commercial DNA extraction kits are a fast and efficient method for obtaining DNA (Sousa et al. 2014); however, in some cases, they may not present satisfactory results due to the great heterogeneity that exists in the chemical composition of plant cells, resulting in the presence of secondary compounds during the extraction process. In addition, polysaccharides form complexes with nucleic acids and inhibit the enzymes used during polymerase chain reaction (PCR), such as Taq polymerase (Shedbalkar et al. 2010; Raimundo et al. 2018). Moreover, DNA extraction by kits has a higher cost, and a few studies in the literature have reported that DNA extraction using a commercial kit generated so little DNA that molecular studies were not possible (Bitencourt et al. 2007). Thus, it is important to modify and adapt the protocols described in the literature and adjust the concentrations of reagents to adapt to the existing variation in the chemical composition of plant tissues (Viana et al. 2015; Almeida et al. 2017).

Because no research has focused on selecting a DNA extraction method for "sucupira branca", this work aimed to compare the efficiency of five protocols for DNA extraction by PCR amplification in "sucupira branca" leaves using three inter-simple sequence repeat (ISSR) primers, aiming to achieve an efficient (simple and rapid), low-cost procedure to obtain high-quality DNA for molecular analysis.

\section{Material and Methods}

\section{Plant material}

Leaves of "sucupira branca" were collected and stored in saturated sodium chloride and cetyltrimethylammonium bromide $(\mathrm{NaCl}-\mathrm{CTAB})$ solution. The samples were kept in a freezer at $-20{ }^{\circ} \mathrm{C}$ for three weeks before DNA extraction.

In general, the use of young leaves is recommended because DNA with a higher purity can be obtained due to the low concentrations of phenolic compounds in young leaves (Azevedo et al. 2019). However, adult "sucupira branca" individuals can reach up to $15 \mathrm{~m}$ in height, and the youngest leaflets are at the top of the plant (Silva et al. 2005).

\section{DNA extraction}

Five DNA extraction methods described by Dellaporta, Wood and Hicks (1983); Doyle and Doyle (1987); Ferreira and Grattapaglia (1995); Romano and Brasileiro (1998); and Khanuja et al. (1999) were analyzed. However, the evaluated methods may require different reagents and/or reagent concentrations due to the variability present in the biochemical composition of plant tissues. In this way, modifications in the weight of foliar tissue and in the quantity of reagents were performed for a greater efficiency in the isolation of the DNA free of impurities and are listed below. However, the concentrations of reagents applied to each extraction solution were prepared as described in the original protocols.

The DNA in each sample was extracted from $100 \mathrm{mg}$ of fresh leaf tissue macerated in liquid nitrogen. To cover all the foliar tissue in the Eppendorf tube, $500 \mu \mathrm{L}$ of DNA extraction buffer was standardized in all samples because for some protocols, lower amounts were not sufficient to submerge all the macerated tissue. To ensure the elimination of oxidizing substances, $10 \mu \mathrm{L}$ of $\beta$-mercaptoethanol was used in each sample, followed by a water bath at $65{ }^{\circ} \mathrm{C}$ for 40 minutes and inverting the tubes for 10 minutes. Subsequently, three washes were performed with $500 \mu \mathrm{L}$ of chloroform:isoamyl alcohol (24:1) for 
deproteinization, and the samples were centrifuged at $10000 \mathrm{rpm}$. After extraction, the pellet was washed with $70 \%$ alcohol three times and dried in air for 30 minutes. After drying, the DNA was diluted in $100 \mu \mathrm{L}$ of Tris-ethylenediamine tetraacetic acid (EDTA), TE buffer (1 mM EDTA, $10 \mathrm{mM}$ Tris- $\mathrm{HCl}, \mathrm{pH}$ 8.0).

\section{DNA quantification and amplification}

For quantification on a $0.8 \%$ agarose gel with $0.5 X$ Tris-borate (TBE), $5 \mu \mathrm{L}$ of each sample and the nonfragmented DNA marker ( $\lambda$ uncut DNA) at a concentration of $100 \mathrm{ng} / \mu \mathrm{L}$ that were separated at $90 \mathrm{~V}$ for 1.5 $\mathrm{h}$. The gels were stained with ethidium bromide, and samples that generated clearer bands were selected for amplification.

Amplifications were performed in a VeritiTM 96 Well Thermal Cycler (Applied Biosystems ${ }^{\circledR}$, USA) with an initial denaturation step of 60 seconds at $94{ }^{\circ} \mathrm{C}$, followed by 40 repetitions of a 45 second cycle at $94{ }^{\circ} \mathrm{C}$ and 45 seconds for annealing, extension at $72^{\circ} \mathrm{C}$ for 120 seconds, and a final step of $72{ }^{\circ} \mathrm{C}$ for 6 minutes; the products were stored at $4{ }^{\circ} \mathrm{C}$. The reagents used for the amplification reaction were as follows: $1.0 \mu \mathrm{L}$ of DNA $(7 \mathrm{ng} / \mu \mathrm{L}), 1 \mathrm{U}$ of Taq polymerase QuatroG, $1.0 \mu \mathrm{L}$ of amplification buffer $(100 \mathrm{mM}$ Tris- $\mathrm{HCl}, \mathrm{pH} 8.4 ; 500 \mathrm{mM}$ $\mathrm{KCl}, \mathrm{pH} 8,5$ ), $0.8 \mathrm{mM}$ dNTP (dATP, dCTP, dGTP, and dTTP), $0.8 \mu \mathrm{M}$ primer, and ultrapure $\mathrm{H}_{2} \mathrm{O}$ in a $10 \mu \mathrm{L}$ final volume. Three ISSR primers, developed by the University of British Columbia, Vancouver, Canada, were used: UBC 812 (5'-GAG AGA GAG AGA GAG AA-3'); UBC 890 (5'-VHV GTG TGT GTG TGT GT-3') and UBC 807 (5'-AGA GAG AGA GAG GT-3'). Amplified products were separated on a $1.5 \%$ agarose gel with $0.5 \mathrm{X}$ TBE buffer at 80 $\mathrm{V}$ for $3 \mathrm{~h}$. The gels were stained with GelRed ${ }^{\mathrm{TM}}$ (Uniscience), visualized under an ultraviolet transilluminator, and documented by comparing the DNA resolution of the samples with a molecular weight marker (Invitrogen) of $1 \mathrm{~kb}$.

\section{Results}

DNA isolation is a primary and critical step in the molecular analysis of any plant species, as DNA quality is often determined by several factors; therefore, the presence of phenolic compounds and other secondary metabolites has many effects on the amount and quality of purified DNA (Leza et al. 2017).

Some extraction procedures were common among the five protocols tested, such as cell lysis, cell separation from other cellular components, DNA purification and isolation. Cell membrane rupture was performed by applying CTAB detergent to the solution, except in the protocol of Dellaporta, Wood and Hicks (1983), who used sodium dodecyl sulfate (SDS). Being positively charged, CTAB forms a complex with negatively charged DNA, and with the aid of $\mathrm{NaCl}$, it aids in the separation of DNA from proteins and the formation of an almost insoluble complex, which facilitates precipitation. In general, the detergents CTAB and SDS are used in plant cell lysis (Cota-Sánchez et al. 2006; Stefanova et al. 2013).

All protocols resulted in the formation of a pellet except the method described by Dellaporta et al. (1983), suggesting that there would be no DNA in this sample, which was confirmed after electrophoresis (Figure 1).

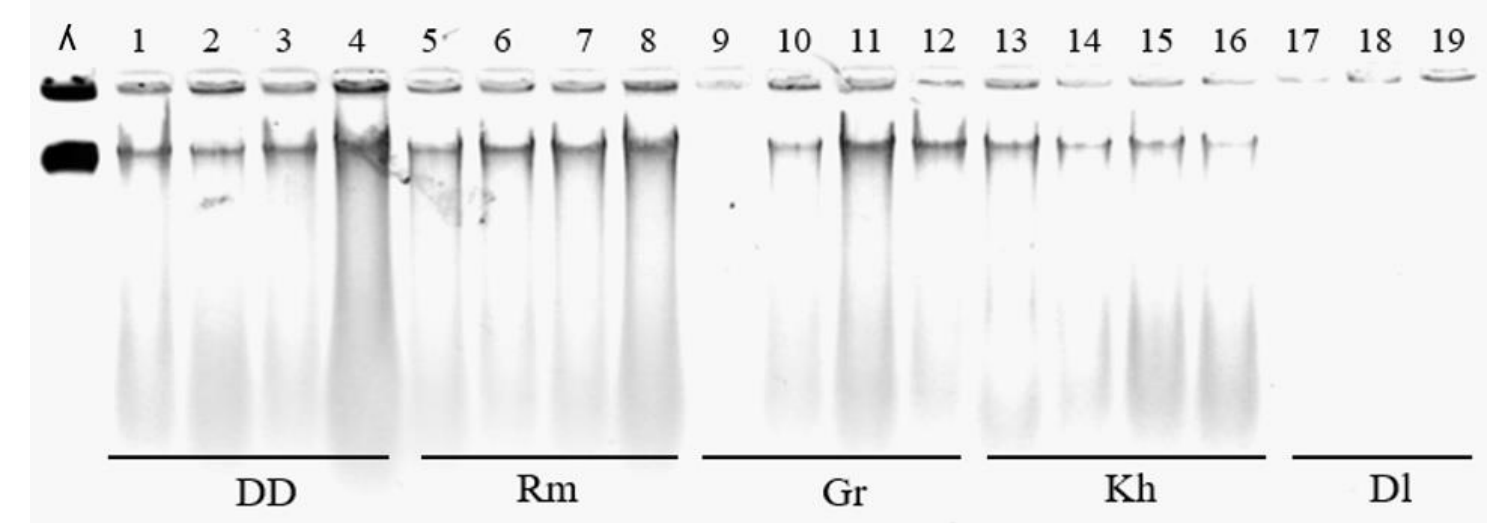

Figure 1. Electrophoretic profile of DNA marker ( $\lambda$ uncut DNA) and DNA extracted from young leaves of

"sucupira branca" in a 0.8\% agarose gel using five protocols: DI = Dellaporta, Wood and Hicks (1983); DD = Doyle and Doyle (1987); Gr = Ferreira and Grattapaglia (1995); Rm = Romano and Brasileiro (1998); $\mathrm{Kh}=$ Khanuja et al. (1999). 
Some research has shown that the CTAB method provides high DNA yields for complex and difficult samples; therefore, most plant DNA extraction protocols described in the literature use the CTAB cationic detergent-based method, with distinct CTAB-based lysis buffer compositions according to species characteristics (Mafra et al. 2008; Danner et al. 2011; Elsanhoty et al. 2011). There are studies that indicate the efficiency of SDS buffer in obtaining good DNA quality and quantity for other legume species, such as soybean (XIA et al., 2019).

In this study, the protocols described by Doyle and Doyle (1987), Ferreira and Grattapaglia (1995) and Romano and Brasileiro (1998) presented more intense bands than the protocol of Khanuja et al. (1999). The average DNA concentrations obtained in these four protocols were 3.25, 3.25, 2.0 and $1.75 \mathrm{ng} / \mu \mathrm{L}$. In the method described by Dellaporta et al. (1983), $0.0 \mathrm{ng} / \mu \mathrm{L}$ of DNA was obtained, confirming the absence of DNA in these samples. Thus, the protocols described by Doyle and Doyle (1987); Romano and Brasileiro (1998); Ferreira and Grattapaglia (1995) were used for the DNA amplification reactions (PCR) with three different ISSR primers (UBC 812; UBC 890 and UBC 807), which generated visible bands; this result indicated that the amount and the quality of the extracted DNA were sufficient to perform these reactions (Figure 2). The presence of polymorphic bands in the electrophoretic profile of PCR products indicates that these primers can be used for genetic diversity analysis in "sucupira branca".

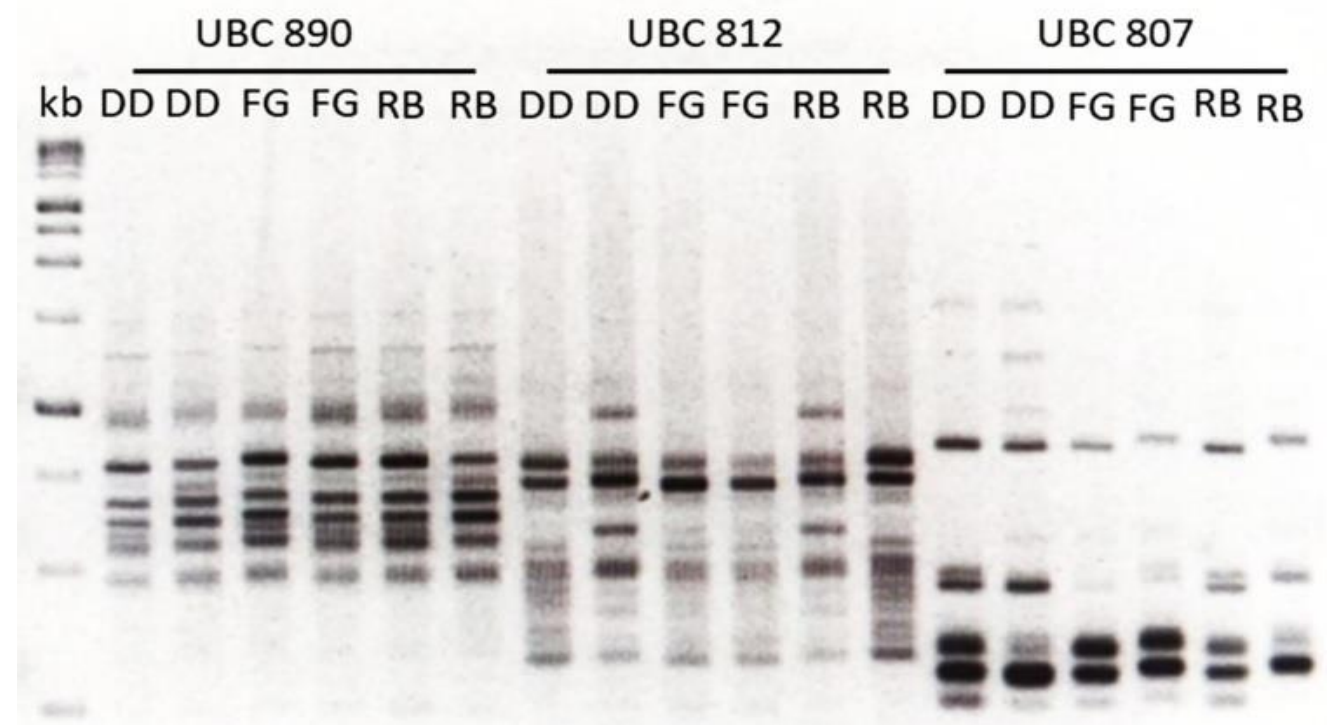

Figure 2. Electrophoretic profile of PCR products using the primers ISSR UBC 890, UBC 812 and UBC 807 and DNA extracted from young leaves of "sucupira branca". DD = Doyle and Doyle (1987); FG = Ferreira and Grattapaglia (1995); RB = Romano and Brasileiro (1998). kb = molecular weight marker (1 kb).

\section{Discussion}

According to Anerao et al. (2017), PCR is considered one of the most efficient techniques to indicate the high quality of extracted DNA, which suggests that the extractions were sufficiently free of proteins and polyphenolic and polysaccharide compounds. Protocol comparisons are crucial, especially when using molecular techniques that require high-quality genomic DNA.

The protocol of Khanuja et al. (1999) presented the lowest concentrations of CTAB, EDTA and Tris$\mathrm{HCl}$ compared to the other methods tested. Interactions between $\mathrm{CTAB}$ and cell membrane proteins contributed to cell lysis, while DNA interaction with phenolic compounds and polysaccharides may inhibit subsequent amplification assays (Raimundo et al. 2018). Therefore, an adequate CTAB concentration is required to ensure high yield and purity of the extracted DNA. Increased $\mathrm{NaCl}$ concentration in the CTAB lysis buffer promotes high solubility of polysaccharides during isopropanol extraction, improving the DNA quality (Syamkumar et al. 2003). The efficiency of the Doyle and Doyle (1987) method for isolating DNA from "sucupira branca" was expected because this method is often used to extract DNA from leaves with high levels of polysaccharide and polyphenol (Leza et al. 2017). The modifications made to the methods described by Ferreira and Grattapaglia (1995); Romano and Brasileiro (1998) also proved to be efficient for the isolation of DNA free of impurities. 
Several methods for plant DNA isolation are available. However, modifications are necessary according to the particularities of each species. In this work, changes in the concentrations of $\beta$ mercaptoethanol and of chloroform: isoamyl alcohol were the main factors for the isolation of DNA free of impurities, because "sucupira branca" plants produce high amounts of phenolic compounds that degrade and contaminate the extracted DNA samples.

\section{Conclusions}

The modifications made to the DNA extraction protocols described by Doyle and Doyle (1987); Ferreira and Grattapaglia (1995); Romano and Brasileiro (1998) were fundamental for efficient DNA extraction from "sucupira branca" leaves, providing a simple and low-cost DNA extraction protocol compared to commercial purification kits and providing quality DNA for genetic analysis. In addition, the ISSR primers UBC 812, UBC 890 and UBC 807 can be selected for molecular analysis in "sucupira branca".

Authors' Contributions: SILVA, J.N.: conception and design, acquisition of data, analysis and interpretation of data, drafting the article, critical review of important intellectual content; VIANA, J.P.G.: critical review of important intellectual content; COSTA, M.F.: critical review of important intellectual content; SÁ, G.H.: acquisition of data; GOMES, M.F.C: conception and design, analysis and interpretation of data, critical review of important intellectual content; FEITOZA, L.L.: critical review of important intellectual content; VALENTE, S.E.S.: conception and design, analysis and interpretation of data, drafting the article, critical review of important intellectual content. All authors have read and approved the final version of the manuscript.

Conflicts of Interest: The authors declare no conflicts of interest.

Ethics Approval: Not applicable.

Acknowledgments: Not applicable.

\section{References}

ALMEIDA, V.M., et al. Comparison of eight methods to isolate genomic DNA from Hancornia speciosa. Genetics and Molecular Research. 2017, 16(3), 1-7. https://doi.org/10.4238/gmr16039724

ANERAO, J., JHA, V. and DESAI, N. Optimization of DNA extraction methods from Garcinia species for ISSR-PCR, RAPD-PCR and DNA barcoding. Asian Journal of Biotechnology. 2017, 9(1), 35-42. https://doi.org/10.3923/ajbkr.2017.35.42

AZÊVEDO, H.S.F., et al. Preservation and maceration of amazon açai leaflet tissue to obtain genomic DNA. Bioscience Journal. 2019, 35(4), 1188-1197. https://doi.org/10.14393/BJ-v35n4a2019-42190

BITENCOURT, J.V.T., et al. Comparison of Different Methodologies for DNA Extraction from Aegla longirostri. Brazilian Archives of Biology and Technology. 2007, 50(6), 989-994. https://doi.org/10.1590/S1516-89132007000700010

BRANDÃO, M. and FERREIRA, P.B.D. Flora apícola do cerrado. Informe Agropecuário, 15(168), 7-14. 1991.

CARVALHO, J.C.T., et al. Anti-inflammatory activity of the crude extract from the fruits of Pterodon emarginatus Vog. Journal of Ethnopharmacology. 1999, 64(2), 127-133. https://doi.org/10.1016/S0378-8741(98)00116-0

CORRÊA, T.C.S. and BERTUCI-JUNIOR, L. Avaliação de quebra de dormência tegumentar em sementes de sucupira branca (Pterodon emarginatus Vog.) submetidas a diferentes tratamentos. Cadernos de Agroecologia. 2012, 7(2), 1-5.

COTA-SÁNCHEZ, J.H., REMARCHUK, K. and UBAYASENA, K. Ready to use DNA extracted with a CTAB method adapted for herbarium specimens and mucilaginous plant tissue. Plant Molecular Biology Reporter. 2006, 24(1), 161-167. https://doi.org/10.1007/BF02914055

DANNER, M.A., et al. Proposta de protocolo para extração de DNA de Jabuticabeira. Ciência Florestal. 2011, 21(2), 363-367.

DELLAPORTA, S.L., WOOD. J. and HICKS, J.B. A plant minipreparation: version II. Plant Molecular Biology Report. 1983, 1(4), 19-20.

https://doi.org/10.1007/BF02712670

DONATI, M., et al. Radical scavenging and antimicrobial activities of Croton zehntneri, Pterodon emarginatus and Schinopsis brasiliensis essential oils and their major constituents: estragole, trans-anethole, $\beta$-caryophyllene and myrcene. Natural Product Research. 2015, 29(10), 939-946. https://doi.org/10.1080/14786419.2014.964709

DOYLE, J.J. and DOYLE, J.L. A rapid DNA isolation procedure for small quantities of fresh leaf tissue. Phytochemical Bulletin. 1987, 19(1), 11-15.

ELSANHOTY, R.M., RAMADAN, M.F. and JANY, K.D. DNA extraction methods for detecting genetically modified foods: a comparative study. Food Chemitry. 2011, 126(4), 1883-1889. https://doi.org/10.1016/j.foodchem.2010.12.013

FERREIRA, M.E. and GRATTAPAGLIA, D. Introdução ao uso de marcadores RAPD e RFLP em análise genética. 1st ed. Brasília: EMBRAPACERNARGEN, 1995. 
KHANUJA, S.P.S., et al. Rapid isolation of DNA from dry and fresh samples of plants producing large amounts of secondarity metabolites and essential oils. Plant Molecular Biology Reporter. 1999, 17(1), 1-7. https://doi.org/10.1023/A:1007528101452

LACERDA, C.M.B. and KAGEYAMA, P.Y. Estrutura genética de duas populações naturais de Myracrodruon urundeuva M. Allemão na Região Semi-árida, Brasil. Revista Árvore. 2003, 27(2), 145-150. https://doi.org/10.1590/S0100-67622003000200004

LEZA, A.B., HAJARE, S.T. and CHAUHAN, N.M. Comparative analysis of DNA extraction methods in two popular varieties of finger millet (Eleusine coracana) from Ethiopia. Biotechnology Journal International. 2017, 20(2), 1-7. https://doi.org/10.9734/BJI/2017/33145

LORENZI, H. Árvores brasileiras: manual de identificação e cultivo de plantas arbóreas do Brasil. 2nd ed. Nova Odessa: Instituto Plantarum de Estudos da Flora Ltda, 1992.

MAFRA, I., et al. Comparative study of DNA extraction methods for soybean derived food products. Food Control. 2008, 19(12), 1183-1190. https://doi.org/10.1016/i.foodcont.2008.01.004

MONDRAGON-JACOBO, C., DOUDAREVA, N. and BORDELON, B.P. DNA extraction from several cacti. HortScience. 2000, 35(6), $1124-1126$. https://doi.org/10.21273/HORTSCl.35.6.1124

OLIVEIRA, A.E., et al. Development of a larvicidal nanoemulsion with Pterodon emarginatus Vogel Oil. PLoS One. 2016, 11(1), 1-16. https://doi.org/10.1371/journal.pone.0145835

OLIVEIRA, G.R.D., et al. Dietary supplementation with plant oils from copaíba (Copaifera langsdorffii) and sucupira (Pterodon emarginatus): quality of physical aspects of eggs stored under different temperatures. Ciência Animal Brasileira. 2018, 19(1), 1-12.

https://doi.org/10.1590/1809-6891v19e-41508

RAIMUNDO, J., REIS, C.M.G. and RIBEIRO, M.M. Rapid, simple and potentially universal method for DNA extraction from Opuntia spp. fresh cladode tissues suitable for PCR amplification. Molecular Biology Reports. 2018, 45(5), 1405-1412. https://doi.org/10.1007/s11033-018-4303-8

ROMANO, E. and BRASILEIRO, A.C., 2015. Extração de DNA de tecidos vegetais. In: BRASILEIRO, A.C.M., CARNEIRO, V.T.C. (Eds.). Manual de transformação genética de plantas. 2nd ed. Brasília: EMBRAPA-PI/EMBRAPA - CENARGEN, pp. 163 -177.

SHEDBALKAR, U.U., et al. Opuntia and other cacti: applications and biotechnological insights. Tropical Plant Biology. 2010, 3(1), 136-150.

https://doi.org/10.1007/s12042-010-9055-0

SILVA, I.D., et al. Efeito do extrato de sucupira (Pterodon emarginatus Vog.) sobre o desenvolvimento de fungos e bactérias fitopatogênicos. Pesquisa Agropecuária Tropical. 2005, 35(2), 109-115.

SILVA-JUNIOR, M.C. 100 Árvores do cerrado: guia de campo. 1st ed. Brasília: LGE, 2005.

STEFANOVA, P., et al. A modified CTAB method for DNA extraction from soybean and meat products. Biotechnology \& Biotechnological Equipment. 2013, 27(3), 3803-3810. https://doi.org/10.5504/BBEQ.2013.0026

SOUSA, C.C., et al. Short Communication Comparison of methods to isolate DNA from Caesalpinia ferrea. Genetics and Molecular Research. 2014, 13(2), 4486-4493. https://doi.org/10.4238/2014.june.16.7

SYAMKUMAR, S., LOWARENCE, B. and SASIKUMAR, B. Isolation and amplification of DNA from rhizomes of turmeric and ginger. Plant Molecular Biology Reporter. 2003, 21(1), 171a-171e. https://doi.org/10.1007/BF02774243

VIANA, J.P.G., et al. Comparison of eight methods of genomic DNA extraction from babassu. Genetics and Molecular Research. 2015, 14(4), 18003-18008. https://doi.org/10.4238/2015.december.22.26

XIA, Y., et al. A modified SDS-based DNA extraction method from raw soybean. Bioscience Reports. 2019, 39(2), 1-10. https://doi.org/10.1042/BSR20182271

Received: 25 April 2020 | Accepted: 12 September 2021 | Published: 29 December 2021

This is an Open Access article distributed under the terms of the Creative Commons Attribution License, which permits unrestricted use, distribution, and reproduction in any medium, provided the original work is properly cited. 